\title{
PENGARUH PENGGUNAAN MOLASES SEBAGAI SUMBER ENERGI PAKAN PENGUAT DALAM RANSUM TERHADAP PERTUMBUHAN TERNAK KELINCI
}

\author{
Sumarni Wuysang, C.A. Rahasia*, J.F. Umboh, Y. L. R. Tulung \\ Fakultas Peternakan Universitas Sam Ratulangi Manado, 95115
}

\begin{abstract}
ABSTRAK
Molasses sudah banyak digunakan sebagai pakan. Penelitian ini bertujuan untuk mengetahui pengaruh penggunaan molases terhadap pertumbuhan kelinci. Penelitian dilaksanakan sejak tanggal 11 Juni sampai tanggal 13 Juli 2016, di Laboratorium Lapang Jurusan Nutrisi Makanan Ternak Fakultas Peternakan Universitas Sam Ratulangi Manado. Penelitian menggunakan 20 ekor kelinci lepas sapih berumur 8 minggu dan menggunakan kandang individu, setiap unit ditempatkan 1 ekor. Rancangan yang digunakan adalah Rancangan Acak Lengkap (RAL), yang terdiri dari 4 perlakuan dan 5 ulangan. Perlakuan yang dimaksud adalah molases dengan beberapa tingkat pemberian dalam ransum, yaitu $\mathrm{R}_{0}=0 \%, \mathrm{R}_{1}=2 \%, \mathrm{R}_{2}=4 \%$, dan $\mathrm{R}_{3}=6 \%$. Variabel yang diukur yaitu konsumsi pakan, pertambahan berat badan, konversi ransum dan konsumsi air minum. Hasil penelitian menunjukkan rataan konsumsi pakanyaitu sebesar 58,1-60,4 g.ekor ${ }^{-1}$.hari ${ }^{-1}$, pertambahan berat badan: 20,1-20,9 g.ekor ${ }^{-1}$.hari ${ }^{-1}$, konversi ransum: 2,86-3,04, dan konsumsi air minum: 127,2-163,8 ml.ekor ${ }^{-1}$.hari ${ }^{-1}$. Berdasarkan hasil analisis sidik ragam, penggunaan molases sebagai pengganti sebagian ransum memberikan pengaruh berbeda tidak nyata $(\mathrm{P}>0,05)$ terhadap konsumsi pakan, pertambahan berat badan, konversi ransum dan konsumsi air minum. Dapat disimpulkan bahwa molases sebagai
\end{abstract}

\footnotetext{
*Korespondensi (corresponding Author)

Email: camelia_rahasia@yahoo.com
}

sumber energi dalam pakan penguat dapat digunakan sampai 6 persen tanpa adanya efek negatif.

Kata kunci : molases, kelinci, ransum, pertumbuhan

\section{ABSTRACT}

\section{UTILIZATION EFFECT OF MOLASSES AS ENERGY SOURCE IN THE DIETS ON GROWING RABBIT} PERFORMANCE. Molasses had been used previously in animal feeds. The present study was conducted to determine the effect of molasses utilization in the diets on growing rabbits. The study was conducted during five weeks at Department of Animal and Feed Science Laboratory, Faculty of Animal Husbandry, University of Sam Ratulangi, Manado. Twenty eight-weeks weaned female rabbits with an initial body weight of 600 $700 \mathrm{gr}$ were used in this trial. Animals were allocated in an individual cage. A Completely Randomized Design (CRD) with 4 treatments and 5 replications was used for analysis of variance. Treatments were formulated as follow: $\mathrm{R}_{0}=100 \%$ basal diet $+0 \%$ molasses; $\mathrm{R}_{1}=98 \%$ basal diet $+2 \%$ molasses; $\mathrm{R}_{2}=96 \%$ basal diet + $4 \%$ molasses; and $\mathrm{R}_{3}=94 \%$ basal diet + $6 \%$ molasses. Variables measured were daily feed consumption, water consumption, daily gain, and feed conversion. Research results showed that average daily feed consumption in the present study ranged from 58.1 to $60.4 \mathrm{~g}$; daily water consumption from 127.2 to 
163.8 liters; daily gain from 20.1 to $20.9 \mathrm{~g}$; and feed conversion ratio of about 3.57 to 3.80. Statistical analysis revealed that utilization of molasses replacing part of basal diets up to $6 \%$ gave no significant differences on daily feed consumption, water consumption, daily gain, and feed conversion ratio. It can be concluded that molasses as an energy source can be utilized up to $6 \%$ in growing rabbit diets without any negative effects.

Keywords: Molasses, diets, growing rabbits performance.

\section{PENDAHULUAN}

Kelinci merupakan ternak yang memiliki prospek yang baik untuk di kembangkan. Daging kelinci diketahui memiliki kandungan lemak yang rendah dengan kandungan protein yang tinggi. Kelinci memiliki kemampuan tumbuh dan berkembang biak dengan cepat serta dapat memanfaatkan pakan yang berasal dari limbah pertanian maupun hasil samping dari industri pangan.

Pakan memegang peranan penting dalam usaha pemeliharaan ternak, karena sebagian besar biaya produksi adalah pakan. Pertumbuhan yang optimal dipengaruhi oleh kualitas dan kuantitas pakan yang dikonsumsi. Pakan penguat atau konsentrat berperan untuk meningkatkan nilai nutrien yang rendah agar memenuhi kebutuhan ternak untuk tumbuh dan berkembang. Salah satu bahan penyusun ransum yang digunakan saat ini masih bersaing dengan kebutuhan manusia seperti jagung. Untuk itu perlu dicari bahan pakan alternatif sumber energi yang murah, tidak bersaing dengan kebutuhan manusia, mudah didapat, dan memiliki nilai nutrisi yang baik. Molases merupakan hasil samping pada industri pengolahan gula dengan wujud cair. Molases merupakan sumber energi yang esensial dengan kandungan gula di dalamnya. Molases telah banyak digunakan sebagai salah satu bahan penyusun ransum dengan kandungan nutrien yang cukup baik. Penelitian ini dilaksanakan untuk mengetahui pengaruh penggunaan molases dalam ransum terhadap pertumbuhan ternak kelinci.

\section{MATERI DAN METODE PENELITIAN}

\section{Tempat dan Waktu Penelitian}

Penelitian ini dilaksanakan di Laboratorium Lapang Jurusan Nutrisi dan Makanan Ternak Fakultas Peternakan Universitas Sam Ratulangi Manado, selama 32 hari sejak tanggal 11 Juni sampai tanggal 13 Juli 2016.

\section{Materi Penelitian}

Penelitian ini menggunakan 20 ekor kelinci lepas sapih berumur 8 minggu dengan berat awal $600-700 \mathrm{~g}$.

\section{Kandang dan Perlengkapan}


Kandang yang digunakan yakni kandang individu yang terbuat dari balok, bambu, dan ram-ram kawat berukuran $45 \times 45 \times 45 \quad \mathrm{~cm}$. Atap kandang menggunakan seng. Masing-masing kandang dilengkapi dengan tempat makan dan minum yang terbuat dari plastik. Alatalat yang digunakan yaitu timbangan digital untuk menimbang ransum dan ternak kelinci, pisau untuk memotong hijauan, wadah untuk menyimpan dan mencampur ransum dan menampung air, alat tulis menulis untuk mencatat data berat badan, konsumsi ransum dan air minum, gelas ukur untuk mengukur air minum yang diberikan.

\section{Ransum Percobaan}

Bahan penyusun ransum terdiri dari jagung, dedak padi, bungkil kelapa, bungkil kedelai, tepung ikan, dan molases. Hijauan yang diberikan adalah daun wortel. Daun wortel ditentukan sebagai hijauan ransum dalam penelitian ini berdasarkan beberapa hasil penelitian terdahulu bahwa daun wortel merupakan salah satu hijauan terbaik di antara beberapa limbah pertanian yang ada. Komposisi nutrien ransum percobaan dan daun wortel dapat dilihat pada Tabel 1.

\section{Metode Penelitian}

\section{Rancangan Percobaan}

Rancangan yang digunakan dalam penelitian ini yaitu Rancangan Acak yang digunakan sesuai petunjuk Steel dan Torrie (1995), sebagai berikut:

$$
\mathrm{Y}_{\mathrm{ij}}=\mu+\tau_{i}+\sum_{i j}
$$

$\mathrm{Y}_{\mathrm{ij}}=$ Variabel yang akan dianalisis pada ulangan ke-i ulangan ke-j

$\mu \quad=$ Rata-rata secara sebenarnya (nilai tengah populasi)

$\tau_{\mathrm{i}}=$ Pengaruh perlakuan ke-i

$\sum_{\mathrm{ij}}=$ Galat eksperimen pada perlakuan ke-i ulangan ke-j

Tabel 1. Komposisi Nutrien Ransum Percobaan Dan Daun Wortel

\begin{tabular}{cccccc}
\hline Bahan Pakan & Bahan Kering & Protein & Serat Kasar & Lemak & $\begin{array}{c}\text { Energi Tercerna } \\
\text { (DE) }\end{array}$ \\
\hline Konsentrat $^{1)}$ & & & & & \\
R0 & 89,22 & 16,41 & 7,39 & 7,46 & 2625,21 \\
R1 & 89,22 & 16,17 & 7,25 & 7,31 & 2621,91 \\
R2 & 89,22 & 15,93 & 7,11 & 7,17 & 2618,60 \\
R3 & 89,22 & 15,68 & 6,97 & 7,02 & 2615,30 \\
Daun Wortel $^{2)}$ & 13,78 & 26,20 & 10,01 & 1,67 & 2483,42 \\
\hline
\end{tabular}

Sumber :1) Berdasarkan perhitungan komposisi zat-zat makanan dari bahan pakan penyusun ransum

2) Mas'ud, 2015 
Data yang diperoleh dianalisis dengan analisis sidik ragam (ANOVA) untuk mengetahui pengaruh perlakuan terhadap variabel yang diukur. Perlakuan disusun sebagai berikut :

$\mathrm{R}_{0}=100 \%$ Ransum Basal $+0 \%$ Molases

$\mathrm{R}_{1}=98 \%$ Ransum Basal $+2 \%$ Molases

$\mathrm{R}_{2}=96 \%$ Ransum Basal $+4 \%$ Molases

$\mathrm{R}_{3}=94 \%$ Ransum Basal $+6 \%$ Molases

\section{Variabel yang diukur}

1. Konsumsi ransum (gram) dihitung berdasarkan jumlah ransum yang diberikan (g.ekor ${ }^{-1} \cdot$ hari $\left.^{-1}\right)$, dikurangi dengan jumlah ransum yang tersisa $\left(\right.$ g.ekor ${ }^{-1} \cdot$ hari $\left.^{-1}\right)$.

2. Pertambahan berat badan (gram) didapatkan dari selisih antara berat badan akhir dengan berat badan awal penimbangan.

3. Konversi ransum yaitu, perbandingan antara rata-rata ransum yang dikonsumsi dengan pertambahan berat badan rata-rata selama periode penelitian.

4. Konsumsi air (ml) diperoleh dari selisih antara jumlah air minum yang diberikan dengan air minum sisa setiap harinya.

\section{Tatalaksana Penelitian}

Sebelum penelitian dilaksanakan, kandang dan lingkungannya dibersihkan, kemudian dilakukan pembersihan dan penataan tempat makan dan minum. Tempat makan dan tempat minum diletakkan secara teratur di 20 unit kandang. Selanjutnya di tiap unit kandang ditempatkan 1 ekor kelinci. Ransum yang diberikan terdiri dari hijauan dan konsentrat. Hijauan yang akan diberikan disediakan satu hari sebelum pemberian, bertujuan agar terjadi pelayuan dengan maksud mencegah perut kembung pada kelinci. Hijauan yang akan diberikan dipotong-potong terlebih dahulu dengan ukuran $\pm 10 \mathrm{~cm}$ menggunakan pisau, kemudian ditimbang begitupun dengan konsentrat. Ransum yang sudah ditimbang langsung diberikan sesuai perlakuan. Pemberian ransum dilakukan dua kali sehari yaitu pagi hari pukul 07.00 am dan malam hari pukul $07.00 \mathrm{pm}$. Sebelum pemberian ransum pada malam hari, sisa ransum pada pagi hari ditimbang dan dicatat terlebih dahulu lalu diganti dengan ransum yang baru begitupun sebaliknya. Pemberian air minum diberikan $300 \mathrm{ml}$ per hari, pemberiannya terdiri dari $200 \mathrm{ml}$ pada pagi hari dan $100 \mathrm{ml}$ pada malam hari. Proses pemberian dan pencatatan dilakukan seperti pemberian ransum. Kemudian dilakukan penimbangan berat badan ternak kelinci dalam setiap 8 hari sekali selama 32 hari. 
HASIL DAN PEMBAHASAN

\section{Pengaruh Perlakuan Terhadap Konsumsi Ransum}

Rataan Konsumsi ransum kelinci selama penelitian dapat dilihat pada Tabel 2. Nilai rataan konsumsi bahan kering (BK) dari masing-masing perlakuan yaitu antara 58,14-60,35 g.ekor ${ }^{-1} \cdot$ hari $^{-1}$. Data diatas tidak jauh berbeda dengan hasil penelitian Nugroho et al. (2012) yang melaporkan bahwa rataan konsumsi bahan kering kelinci berkisar antara 54,6-57,5 gram.ekor ${ }^{-1}$.hari- Berdasarkan hasil analisis sidik ragam, menunjukkan bahwa penggunaan molases dalam ransum terhadap konsumsi kelinci memberikan pengaruh yang berbeda tidak nyata $(\mathrm{P}>0,05)$. Hal ini berarti bahwa penggunaan molases hingga taraf $6 \%$ dalam konsentrat memberikan respon yang sama dengan ransum dasar (kontrol). Hal ini diduga karena ransum diberikan dalam bentuk pelet sehingga memiliki tekstur, bau, rasa, dan suhu yang hampir sama. Pernyataan tersebut didukung Polii (2015), dimana salah satu faktor yang mempengaruhi konsumsi ransum adalah palatabilitas. Nugroho et al. (2012) menambahkan bahwa ransum yang diberikan dalam bentuk pelet mempengaruhi konsumsi ransum, di mana ransum dalam bentuk pelet lebih disukai dan dikonsumsi lebih banyak dibanding dengan ransum dalam bentuk mash. Mutu ransum juga mempengaruhi konsumsi. Qisthon (2012) menambahkan bahwa kelinci akan berhenti makan apabila energi yang dikonsumsi telah cukup untuk kebutuhan metabolisme.

Masing-masing ransum perlakuan menunjukkan perbandingan konsumsi energi yang hampir sama. Energi yang relatif sama pada masing-masing ransum menyebabkan kelinci mengkonsumsi ransum dalam jumlah yang hampir sama. Konsumsi air minum ternak kelinci dalam penelitian ini berkisar antara $127,1-163,8$ ml.ekor ${ }^{-1}$.hari ${ }^{-1}$. Konsumsi air minum ternak kelinci dalam penelitian ini lebih tinggi dibandingkan penelitian dari

Tabel 2. Rataan Konsumsi Bahan Kering, Energi, Protein, Lemak, Dan Air Minum Pada Ternak Kelinci

\begin{tabular}{|c|c|c|c|c|}
\hline \multirow[t]{2}{*}{ Konsumsi } & \multicolumn{4}{|c|}{ Perlakuan } \\
\hline & R0 & R1 & R2 & R3 \\
\hline BK (g.ekor ${ }^{-1} \cdot$ hari $\left.^{-1}\right)$ & 58,14 & 58,77 & 59,96 & 60,35 \\
\hline Protein ( g.ekor ${ }^{-1}$.hari $^{-1}$ ) & 9,54 & 9,50 & 9,55 & 9,46 \\
\hline Lemak ( g.ekor ${ }^{-1} \cdot$ hari $^{-1}$ ) & 4,34 & 4,30 & 4,30 & 4,24 \\
\hline Energi $(\mathrm{kkal} / \mathrm{kg})$ & 152,63 & 154,09 & 157,01 & 157,83 \\
\hline Air minum $\left(\right.$ ml.ekor ${ }^{-1}$ hari $\left.^{-1}\right)$ & 127,15 & 150,16 & 159,085 & 163,79 \\
\hline
\end{tabular}

Keterangan: Pengaruh perlakuan berbeda tidak nyata $(\mathrm{P}>0.05)$ 
Candradiarta et al. (2014) yang melaporkan bahwa konsumsi air minum kelinci adalah 109,97-120,29 ml.ekor ${ }^{-}$ ${ }^{1}$.hari ${ }^{-1}$. Walaupun data konsumsi air minum menunjukkan pola yang semakin meningkat dengan semakin meningkatnya penggunaan molases dalam ransum, namun peningkatan jumlah konsumsi air minum dalam penelitian ini belum sampai pada tingkat yang berbeda nyata $(\mathrm{P}>0,05)$. Tidak adanya perbedaan yang nyata antar perlakuan terhadap konsumsi air minum dalam penelitian ini dapat dimengerti karena jumlah konsumsi ransum (BK), dan zat-zat makanan seperti protein, lemak, dan energi yang berbeda tidak nyata antar perlakuan dalam penelitian ini (Tabel 2). Salah satu faktor yang mempengaruhi jumlah konsumsi air minum yaitu suhu lingkungan (NRC, 1977). Suhu lingkungan dalam penelitian ini hampir konstan baik pada pagi, siang, dan malan tidak berbeda; serta tidak berfluktuasi sehingga jumlah konsumsi air minum juga tidak dipengaruhi secara signifikan.

\section{Pengaruh Perlakuan Terhadap Pertambahan Berat Badan dan Konversi Ransum}

Nilai rataan pertambahan berat badan dari masing-masing perlakuan yaitu antara 20,06-20,88 g.ekor ${ }^{-1}$ hari $^{-1}$ (Tabel 3). Angka pertambahan berat badan kelinci dalam penelitian ini sejalan dengan hasil penelitian Puspani et al. (2015) yang melaporkan angka pertambahan berat badan kelinci berkisar 19,60-21,20 g.ekor ${ }^{1}$.hari ${ }^{-1}$. Polii (2015) menambahkan bahwa pertambahan berat badan kelinci berkisar antara 11,73-16,74. Hasil analisis sidik ragam menunjukkan bahwa penggunaan molases dalam ransum terhadap pertambahan berat badan kelinci memberikan pengaruh yang berbeda tidak nyata $(\mathrm{P}>0,05)$. Hal ini berarti bahwa penggunaan molases hingga taraf $6 \%$ dalam konsentrat menunjukkan respon yang sama dengan ransum dasar. Hasil analisis varians menunjukkan bahwa penggunaan molases dalam ransum kelinci memberikan pengaruh yang berbeda tidak nyata $(\mathrm{P}>0,05)$ terhadap konversi ransum.

Tabel 3. Rataan Pertambahan Berat Badan Dan Konversi Ransum Kelinci

\begin{tabular}{lcccc}
\hline \multirow{2}{*}{\multicolumn{1}{c}{ Parameter }} & R0 & R1 & R2 & R3 \\
\cline { 2 - 5 } & & & \\
Pertambahan Berat Badan & 20,41 & 20,88 & 20,11 & 20,06 \\
$\left(\right.$ g.ekor $^{-1}$.hari ${ }^{-1}$ ) & 2,86 & 2,82 & 3,00 & 3,04 \\
Konversi Ransum $^{\text {Kons }}$ &
\end{tabular}

Keterangan: Pengaruh perlakuan berbeda tidak nyata $(\mathrm{P}>0.05)$ 
Konversi ransum yang berbeda tidak nyata disebabkan oleh tingkat konsumsi dan pertambahan berat badan yang berbeda tidak nyata. Pernyataan tersebut didukung oleh Basuki (2002) bahwa konversi ransum sangat dipengaruhi oleh konsumsi bahan kering dan pertambahan berat badan harian ternak.

\section{KESIMPULAN}

Dapat disimpulkan bahwa molases sebagai sumber energi dalam pakan penguat dapat digunakan sampai 6 persen tanpa adanya efek negatif.

\section{DAFTAR PUSTAKA}

Basuki, P. 2002. Pengantar Ilmu ternak Potong dan Kerja. Bahan Kuliah. Fakultas Peternakan Universitas Gadjah Mada. Yogyakarta.

Candradiarta, I P. M., I M. Nuriyasa, dan I K. Sumadi. 2014. Performans kelinci yang dipelihara pada kepadatan ternak dan pemberian ransum dengan imbangan energi dan protein berbeda. Journal Peternakan Tropika Vol. 2(2): 274286.

Cheeke, P. R. 1991. Applied Animal Nutrition Feeds and Feeding. MacMillan Publ. Co. New York., Collier MacMillan Canada. Toronto. pp. 425-430.
Mas'ud, C. S. 2015. Pengaruh pemberian beberapa jenis hijauan terhadap performans ternak kelinci. Jurnal Zootek Vol. 35(2): 289-94.

NRC. 1977. Nutrien Requirement of Rabbit. 2nd revised edition. National Academy of Sciences, Washington D.C. p 10.

Nugroho, S. S., P. S. B. Subur, dan Panjono. 2012. Pengaruh pengunaan konsentrat dalam bentuk pelet dan mash pada pakan dasar rumput lapangan terhadap palatabilitas dan kinerja produksi kelinci jantan. Buletin Peternakan Vol. 36(3): 169173.

Polii, P. 2015. Pengaruh penambahan zat aditif (enzim dan asam organik) dengan protein tinggi dan rendah pada pakan berbasis dedak terhadap performan kelinci. Jurnal Zootek Vol. 35(2): 280-288.

Puspani, E., N. G. K. Roni, I. M. Nuriyasa. 2015. Performans dan indeks kelembaban suhu kelinci jantan (lepus nigricollis) yang dipelihara dengan luas lantai kandang dan diberi ransum dengan imbangan energi dan protein berbeda. Majalah Ilmiah Peternakan Vol. 18(1): $1-4$

Qisthon, A. 2012. Pengaruh imbangan hijauan-konsentrat dan waktu pemberian ransum terhadap produktivitas kelinci lokal jantan. Jurnal Penelitian Pertanian Terapan Vol. 12 (2): 69-74

Steel, R. C. dan J.H. Torrie J. H. 1995. Prinsip dan Prosedur Statistika. Gramedia Pustaka Utama. Jakarta 